\title{
Reproductive cycle of male wall lizard, Podarcis vaucheri (Reptilia: Sauria: Lacertidae), in Djurdjura, Northern Algeria
}

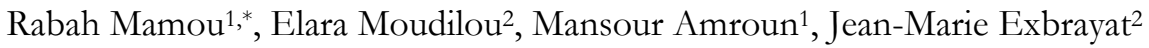 \\ ${ }^{1}$ Laboratoire d'écologie des vertébrés, University Mouloud MAMMERI of Tizi Ouzou, Algeria. \\ ${ }^{2}$ University of Lyon, UMRS 449, General biology - Reproduction and comparative development, Lyon \\ Catholic University, EPHE/PSL, 10 place des Archives, 69288 Lyon Cedex 02, France. \\ *Correspondence: E-mail: mamou.rabah@yahoo.fr
}

Received: 15 February 2017; returned for review: 5 April 2017; accepted 4 September 2017.

The reproductive cycle of male wall lizard Podarcis vaucheri (Boulenger, 1905) living in Djurdjura Mountain, was analyzed from April until October 2014. Its seasonal mixed-type cycle was characterized by three phases: sexual activity, quiescence and recrudescence. After the emergence of lizards from hibernation, an intense sexual activity was observed in spring (April, May, and June), at which the testicular weight and seminiferous tubules diameter reached their maximal values. At this period, spermiogenesis was also maximal and the spermiation allowed the release of a large quantity of spermatozoa in both the seminiferous tubules and epididymis lumen. In July, a short sexual resting period followed, during which the testes mass and seminiferous tubules diameter decreased. Spermatogonia and some primary spermatocytes were observed against the wall of seminiferous tubules. The recrudescence period (August, September and October) was characterized by a progressive increase of the testis weight and seminiferous tubules diameter. Spermatocytogenesis began in August, and spermiogenesis occurred in September and October, before the diapause period. However, the presence of spermatozoids was not signaled in the epididymis lumen. Field observations and microscopic evidence of testis showed that both sexes reproduced synchronously during spring and early summer.

Key words: Algeria; Djurdjura; lizard; Podarcis vaucheri; reproductive cycle; spermatogenesis.

Reproduction imposes high-energy requirements, illustrated by a large diversity in terms of resource acquisition and allocation strategies (Jönsson, 1997). Seasonal breeding represents a valuable strategy in order to use this energy economically, but the reproductive timing becomes one of the most critical issues in the lizard's biology (James \& SHINe, 1985). For that, the reproduction occurs when the environment is the most favorable to off- spring survival and when parents can physiologically sustain reproduction with the lowest cost (Whittier \& CRews, 1987; Pianka \& VitT, 2003).

Timing of reproductive activity is widely variable in lizards (MANRÍQUEZMorán et al., 2005; CArretero, 2006; Villagrán-Santa Cruz et al., 2009; GribBINS, 2011): in temperate-zones, breeding takes place in spring and early summer, with the reproductive season being longer 
in coastal than in continental populations (Carretero \& Llorente, 1995,1997; Galán, 1997; Carretero et al., 2006a, Al-Amri et al., 2012), while in cold and high-altitude environments, mating occurs later in the season and lizards exhibit a short breeding period (Saint-Girons \& DuguY, 1970; Hraoui-Bloquet, 1985; Hraoui-Bloquet \& Bloquet, 1988; Braña et al., 1990; Olsson \& Shine, 1999; Roig et al., 2000; Arribas \& GALÁN, 2005). Further, in desert environments reproduction can be postponed as well as anticipated compared to temperate zones (Hammouche \& GernigonSpychalowicz, 1996; Намmouche et al., 2007; GoldBerg, 2013), and can continue until autumn (GolDberG, 2013). Lastly, it is in tropical areas that lizards exhibit the highest variability of reproductive patterns, ranging from continuous to seasonal reproduction (FITCH, 1970; JAMES \& Shine, 1985; Jenssen \& Nunez, 1994; PIANKA \& VitT, 2003; HuAng, 2010; MÉndeZDE LA CRUz et al., 2013).

Besides the environmental conditions, several studies showed reproductive cycles to be influenced also by the interaction between endogenous and exogenous factors (Licht et al., 1969; Licht, 1972; AngeLiNi et al., 1976; LofTS, 1978; MARIon, 1982; Jenssen \& Nunez, 1994; Carretero, 2006). On one hand, indeed, the gonadal and hormonal activity can be considered the main endogenous mechanisms controlling reproductive cycles (DíAz et al., 1994; IKEUCHI, 2004). Being partly predetermined (ANGelini et al., 1976), it is also expected that these mechanism are subject to some kind of phylogenetic constrains (Dunham \& Miles, 1985; Carretero, 2006), which can limit the observed environmental and geo- graphic variability. On the other hand, the relationships between reproductive cycles and environmental variables suggest that the endogenous mechanisms can plastically respond to climatic components, such as temperature (Licht, 1971,1973; Aldridge, 1975; Angelini et al., 1976; Marion, 1982; Flemming, 1993; Carretero, 2006; AbuZINADAH, 2008), precipitation (JENSSEN \& NunEz, 1994), photoperiod (Licht, 1971,1973; Dunham \& Miles, 1985; FlemMING, 1993; CARRETERo, 2006), or other environmental features, like food availability (Lofts, 1978; Marion, 1982; Colli et al., 2003; Domínguez et al., 2010).

The seasonal testicular cycle in lizards was described in several species (AL-AmRI et al., 2013). Specifically, for temperate regions three spermatogenic cycles were described: i) the vernal or prenuptial type, where spermatogenesis occurs during spring, immediately before or even during breeding (Licht et al., 1969; SAInt-Girons, 1982; CARretero, 2006); ii) the postnuptial type, where spermatogenesis is held during summer of the previous year (SAINTGirons, 1982; Carretero, 2006; HraouiBloquet et al., 2007); iii) an finally the mixed type, where spermatogenesis begins at the end of summer and is interrupted in winter (Licht et al., 1969; Saint-Girons, 1982; Carretero, 2006). However, Saint-Girons (1982) recognized two sub-types of this cycle. The first sub-type corresponds to the classical definition, with spermiogenesis extending until spring of the following season. While in the second sub-type, there are two periods of spermiogenesis, spermatozoa are already produced in autumn of the previous season and continues in spring after hibernation. Whatever the 
cycle, in most cases spermatogenesis is synchronized with vitellogenesis and ovulation in females (PiAnKa \& VITT, 2003; Carretero, 2006).

Lizards of the genus Podarcis (WAGLER 1830) represent a group that has evolved and diversified in the Mediterranean Basin (ArNold et al., 2007). An exemplary case is that of the Podarcis hispanicus complex, which is among the most studied European reptiles, and is characterized by a high genetic diversity (Kaliontzopoulou et al., 2011). The inclusion of genetic sequences from North African specimens has allowed the separation of $P$. vaucheri from the hispanicus complex, and elevating it to the species rank (Oliverio et al., 2000; BusACK et al., 2005). In addition, morphological and phylogenetic studies of Iberian and North African populations (Oliverio et al., 2000; Busack et al., 2005; Рinho et al., 2006,2007; LARBes et al., 2007; Lima et al., 2009; Renoult et al., 2010; KaliontzopouLou et al., 2011,2012) have shown the occurrence of several evolutionary lineages suggesting that Podarcis vaucheri can be considered a species complex. Furthermore, very few information is available, especially on the ecology and physiology of this species. Notably, even if some previous studies have provided data on trophic ecology (CARRetero et al., 2006b; Mamou et al., 2016), thermal biology (Veríssimo \& CARRETERO, 2009), and parasitology (CARretero et al., 2011; Damas-Moreira et al., 2014), none of them has focused on describing the reproductive cycle of this variable species.

The aim of the present work was to describe the spermatogenic cycle of male wall lizards Podarcis vaucheri based on the histological analysis of testis, in order to provide some preliminary information about its reproductive strategy.

\section{Material and Methods}

\section{Site of study}

Tala Guilef is located in the western part of the northern slope of the Djurdjura Mountain (Djurdjura National Park), Kabylie, Algeria. It is located approximately $140 \mathrm{~km}$ southeast of Algiers and $45 \mathrm{~km}$ south west of Tizi Ouzou $\left(36^{\circ} 39^{\prime}\right.$ N, $4^{\circ} 01^{\prime}$ E). The region is characterized by a mountain climate influenced by the Mediterranean Sea, and belongs to the humid climate scene (Hamdine et al., 1993).

The specimens were collected in a rocky environment particularly attractive for this species, characterized by the presence of stones and rocks from the Haïzer massif and bushy vegetation including: Crataegus monogyna, Crataegus laciniata, Rubus ulmifolius, Rosa canina, Rosa sicula, Prunus prostrata and Berberis hispanica. In grass stratum, we essentially found: $A n$ themis kabilica, Artemisia absintium, Astragalus armatus, Eryngium tricuspedatum, Euphorbia luteola and Ferula communis.

\section{Data analysis}

Adult males of $P$. vaucheri were collected monthly (between the tenth and the twenty-fifth day of each month; three individuals/month), from April until October 2014. The snout-vent length (SVL) of each individual was measured using a digital caliper $( \pm 0.01 \mathrm{~mm})$. After dissection, the left testes were removed, weighted with a digital balance $( \pm 0.0001 \mathrm{~g})$, and fixed with buffered formalin for 24 hours, and then preserved in ethanol $70^{\circ}$. The tissues 
were dehydrated in a graded series of ethanol, cleared in butanol prior to be infiltrated and embedded in paraffin. 5 $\mu \mathrm{m}$ sections were stained with hematoxylin-eosin, following standard histological protocols.

Spermatogenic activity was assessed qualitatively by determining the various stages of germ cells. The presence of spermatozoa and secretions in the epididymis lumen were also noted. For a quantitative characterization of testis activity, three measures were taken: the (i) number and (ii) diameter of seminiferous tubes, and (iii) epididymis epithelium thickness. These measures were repeated on three randomly selected testis sections for each individual (Table S1).

Sections of each testis were examined and photographed using a Nikon Eclipse E400 light microscope, equipped with a Nikon digital DXM1200 camera coupled with a picture analyzer Nis-Element BR 3.1(Lucia software).

For the data analysis, the mean value of each histological parameter among the three sections of each individual was considered. All parameters were Log transformed, and comparisons between the different measurements were performed with ANCOVA, using the logarithm of SVL as a covariate. Further, to investigate the influence of body size in the gonadal development, we used a Pearson correlation between SVL and testis weight.

\section{Results}

Mean snout-vent length (SVL) of lizards was $54.73 \pm 0.50 \mathrm{~mm}$, ranging between 50.85 and $58.74 \mathrm{~mm}$. A positive correlation was found between testicular

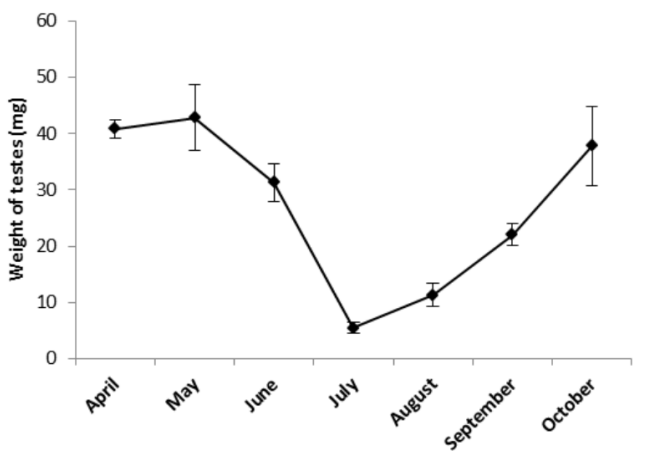

Figure 1: Monthly variation of mean weight testes in Podarcis vaucheri.

weight and body size (SVL) $(\mathrm{r}=0.44, P=$ 0.047). The weight of testis varied significantly throughout the months (ANCOVA $F_{6,13}=44.51, P<0.0001$ ), and the spermatogenesis cycle of $P$. vaucheri might be divided into three main phases (Fig. 1): i) the phase of sexual activity (April, May, June), which was characterized by the highest weight; a short period of regression and a sexual quiescence (July), during which the testis weight decreased; a recrudescence phase (August, September, October), where the testicular weight started to increase (August), reaching its maximum in October, just before the period of hibernation (November March).

The average number of seminiferous tubules by section oscillated between 45 and 55 (Fig. 2a), and did not vary along the season $\left(\mathrm{F}_{6,13}=0.6, P=0.726\right)$. On the contrary, the mean diameter of the seminiferous tubules showed a clear monthly variation $\left(F_{6,13}=9.18, P=0.005\right.$; Fig. $\left.2 b\right)$, peaking during the breeding season (April -June). The sexual resting period was characterized by a maximal regression of the seminiferous tubules diameter with an 

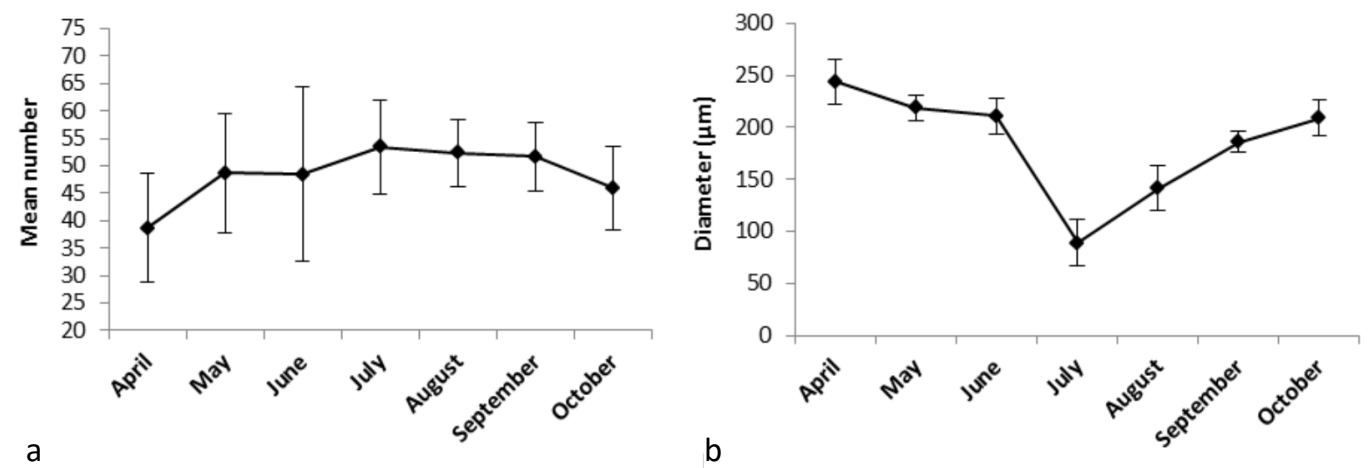

Figure 2: Monthly variation of the (a) mean number and (b) diameter of the seminiferous tubules in Podarcis vaucheri.

absence of lumen. During the period of recrudescence this parameter increased progressively again, with the lumen remaining absent in August. The evolution of the diameter of seminiferous tubules corresponded to the resumption of testicular activity interrupted in November by the temperature decrease, and followed by the beginning of hibernation.

The thickness of the epididymis epithelium showed a significant monthly variations $\left(\mathrm{F}_{6,13}=32.23, P<0.001\right.$; Fig. 3$)$. During the phase of sexual activity this parameter was at maximum, while a sudden reduction of the height was observed in July, persisting until October.

The examination of histological sections revealed some variations of the different categories of germinal cells during the reproductive cycle (Fig. 4). After the emergence of lizards in spring (sexual activity), the spermiogenesis was maximal and persisted until June, so, all sperm cells categories were observed (Fig. 4a), with a decrease of spermatocytes number. The spermiation allowed the release of a large quantity of spermatozoa in the lumen of the seminiferous tubules and epididymis. Moreover, the morpho-functional characteristics of the epididymis have changed; the epithelial cells became secreting and take a prismatic shape (Fig. $4 \mathrm{~b}$ ).

In July, at sexual rest, the seminiferous tubules contained spermatogonia and some primary spermatocytes (Fig. 4c). In August, at the beginning of the recrudescence period, the seminiferous tubules showed a lot of primary and secondary spermatocytes, and some young spermatids (Fig. 5a). In September and October spermiogenesis occurred, and a large number of spermatid and spermatozoa were found in the seminiferous tubules

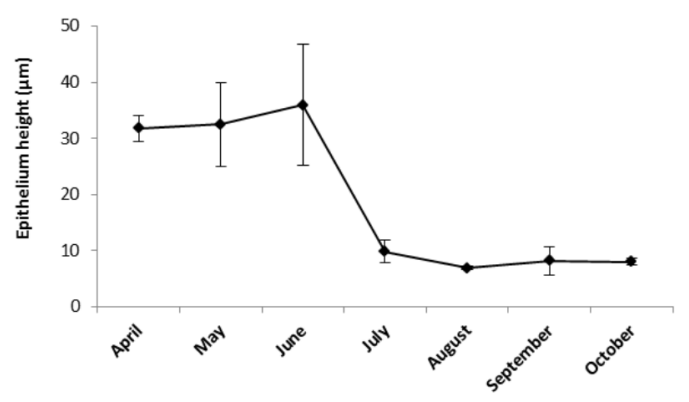

Figure 3: Monthly variation of the epididymis epithelium height in Podarcis vaucheri. 

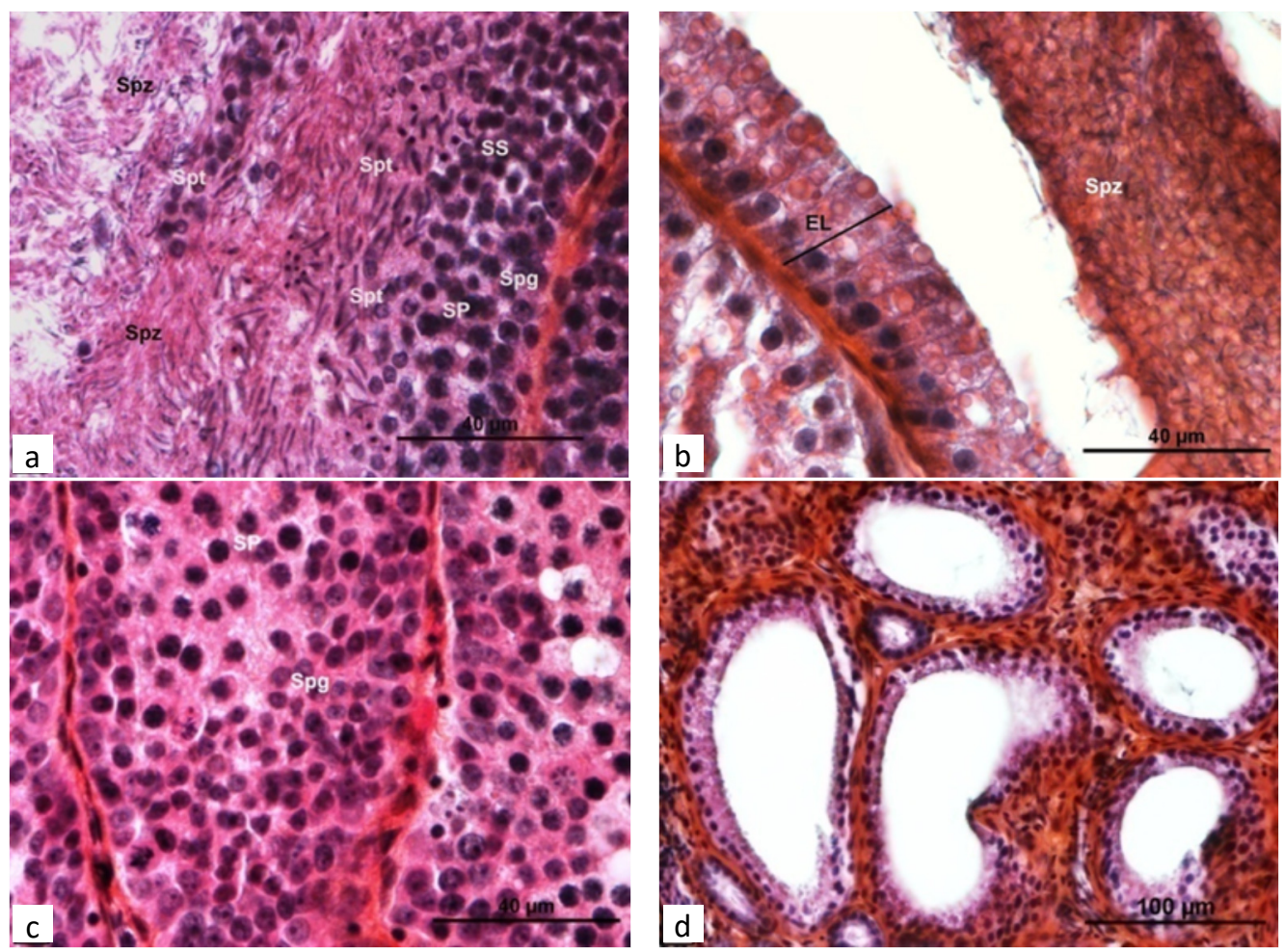

Figure 4: Testis and epididymis histological sections during the sexual activity phase (April, May, June) and sexual rest phase (July) of the reproductive cycle of Podarcis vaucheri. (a) Seminiferous tubules during the sexual activity phase containing all cell categories: spermatogonia (Spg), primary spermatocytes (SP), secondary spermatocytes (SS), spermatids (Spt) and spermatozoa (Spz). (b) Observation of spermatozoa in the epididymis lumen during the sexual activity phase. EL: Epithelium layer. (c) Seminiferous tubules during the sexual rest phase containing only spermatogonia (Spg) and some primary spermatocytes (SP). (d) Empty epididymis lumen during the sexual rest phase.

lumen (Fig. 5c).

In spite of an active spermiogenesis in autumn accompanied with the presence of mature spermatozoids in the lumen of the seminiferous tubules, the epididymis lumen remained empty (Fig. 5d).

\section{Discussion}

The spermatogenic cycle of Podarcis vaucheri is of the "mixed-type", in agreement with what is the dominant pattern in temperate lizards (LICHT et al., 1969; SAINT-
Girons, 1982; Carretero, 2006), especially those belonging to the genera Lacerta s.l. and Podarcis (Saint-Girons \& Dugur, 1970; Angelini et al., 1979; HraouiBloquet, 1985; Hraoui-Bloquet \& Bloquet, 1988; Braña et al., 1990; Castilla \& Bauwens, 1990; Galán, 1996; Amat et al., 2000; Roig et al., 2000; CArretero et al., 2006a). Males of P. vaucheri exhibited an intense sexual activity in April after the hibernation phase, followed by an interruption of the spermatogenesis in June. 

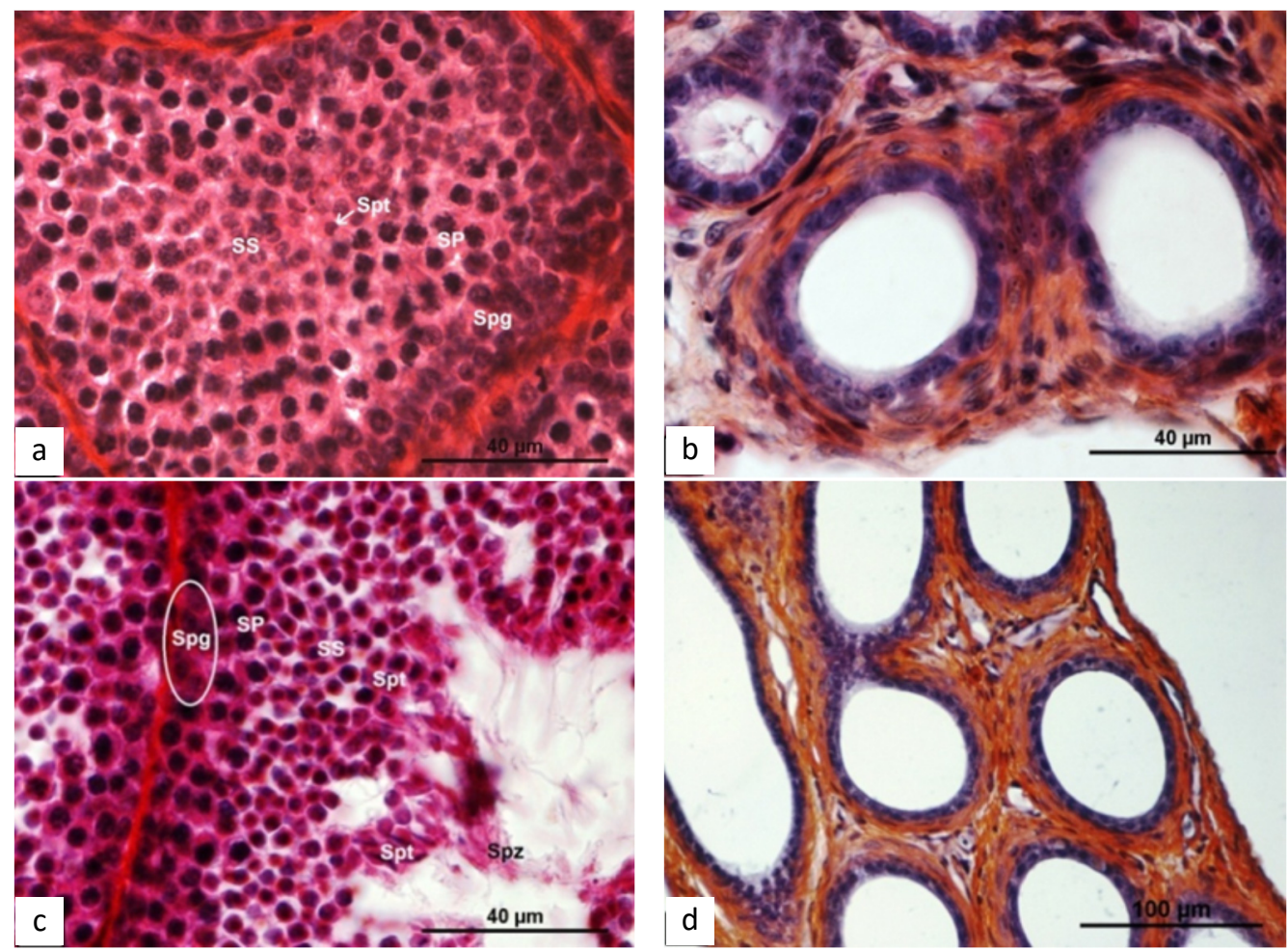

Figure 5: Testis and epididymis histological sections during the early recrudescence phase (August) and autumnal spermiogenesis (September and October) of the reproductive cycle of Podarcis vaucheri. (a) Seminiferous tubules at the beginning of spermatocytogenesis during the early recrudescence phase. (b) Empty epididymis lumen during the early recrudescence phase. (c) All cell categories were observed in the seminiferous tubules during the autumnal spermiogenesis. (d) Epididymis lumen remains empty during the autumnal spermiogenesis. For abbreviations, see Figure 4.

Then, a short sexual resting phase was observed during the hot period of the year, specifically in July and at the beginning of August. This period was characterized by the maximal decrease of the morphological characters, with a disappearance of the lumen in the seminiferous tubes, and only the presence of spermatogonia. Testicular recrudescence started early in late summer (in August) and some young spermatides were already observable. Testis weight increased progressively until the onset of hibernation; and that is accompanied with a development of the seminiferous tubules corresponding to the spermatogenic activity. These observations are in agreement with those of mountains populations, such as Phoenicolacerta laevis (Mahrouka-Sannine Mount in Lebanon; Hraoui-Bloquet, 1985; HraouiBloquet \& Bloquet, 1988), P. muralis (Orédon Biologic Station of High Pyrenees in France; SAInt-Girons \& Duguy, 1970), and Iberolacerta monticola (high and low 
altitudes in Asturias in northern Spain; BRAÑA et al., 1990). However, a very early stop of the spermatogenesis was reported at the end of May in Phoenicolacerta laevis (Hraoui-Bloquet, 1985; Hraoui-Bloquet \& Bloquet, 1988), which is not the case in P. vaucheri.

In addition to the obvious spring testicular activity, another active spermiogenesis was also found in September and October. Finally, this defines two periods of spermiogenesis, corresponding to the second sub-type of the mixed cycle (SAINTGirons, 1982). Similar results were already observed in several Mediterranean lacertids such as Podarcis muralis (SAINTGirons \& Dugur, 1970), Podarcis siculus campestris (ANGELINi et al., 1979), Zootoca vivipara (Roig et al., 2000), Podarcis bocagei (CArretero et al., 2006a), Iberolacerta monticola cantabrica (BrAÑa et al., 1990), Phoenicolacerta kulzeri (RIzK \& NASSAR, 2015) and Phoenicolacerta laevis (Hraoui-Bloquet, 1985; Hraoui-Bloquet \& Bloquet, 1988). This autumnal spermiogenesis has been interpreted as an abortive spermatogenesis (ANGelini et al., 1979), or as a potential second reproductive season (CARretero, 2006).

In addition, no follow-up was possible during winter because of the local climate characterizing the Tala Guilef sector. Snowing time remained from November until March in this region (HAmDine et al., 1993), reducing the period of lizards' activity to seven months, and thus influencing the reproductive cycle. Wall lizard Podarcis vaucheri from Djurdjura did not exhibit any sperm storage in the epididymis during hibernation. Even though spermatozoa were already present in autumn, these re- mained in the testes. Hence, males can be regarded as unfertile during this period (Angelini et al., 1979; Roig et al., 2000; Carretero et al., 2006a; Rizk \& Nassar, 2015). They became fertile in spring only when spermatozoa migrated to the epididymis. Moreover, during the phase of sexual activity, a hypertrophy of the epididymis resulted in an increase of epithelium height and accumulation of secretory granules in its lumen. These various substances secreted by the epithelial cells seem to perform a significant role in the spermatozoa maturation (FERREIRA et al., 2009; Al-Amri et al., 2013). However, the epididymis cycle of $P$. vaucheri was similar to that of Podarcis bocagei (GALÁN, 1996), P. muralis (Saint-Girons \& Duguy, 1970), Iberolacerta monticola (BRAÑA et al., 1990), Acanthodactylus erythrurus (Carretero \& Llorente, 1995), Psammodromus algirus (CARretero \& LIorente, 1997), and seems different from that of Timon lepidus (CAstilla \& Bauwens, 1990) and Phoenicolacerta laevis (Hraoui-Bloquet, 1985; Hraoui-Bloquet \& Bloquet, 1988), where the secondary sexual characters are well developed in both autumn and spring. RIzK \& NASSAR (2015) reported also this post-hibernation activity in Phoenicolacerta kulzeri, with the presence of spermatozoa and secretory granules in the epididymis only in spring. However, the occurrence of spermatozoa in the testes and epididymis in spring and autumn was reported in Liolaemus species from Patagonian, Argentina (Medina \& Ibargüengoytía, 2010).

Both the histological analysis of testes and field observations showed the reproduction period lasting three months, from 
April to June. In the field, several malefemale pairs were seen in copulation positions, females with recent copulation scars were found, and those captured in June were pregnant (pers. obs.). This led to think that spermatogenesis and oogenesis are synchronous, and that mating really lead to fertilization. If so, the cycle of reproduction of $P$. vaucheri would belong to the associated type, which is common in temperate climate (Hraoui-Bloquet, 1985; Hraoui-Bloquet \& Bloquet, 1988; Аmat et al., 2000; Roig et al., 2000; CARRETERo et al., 2006a). According to the definition of Whittier \& Crews (1987), in the associated reproductive pattern, male mating behavior coincides with the time of the year at which gonads are enlarged and actively producing gametes, while in the dissociated reproductive pattern, spermatogenesis occurred before mating and consequently the gametes are stored until the mating period (e.g. in epididymis or spermatophores).

In conclusion, data presented here allowed us to shed light on some of the adaptive strategies used by the wall lizard Podarcis vaucheri in Djurdjura Mountain. Our results showed that timing of spermatogenesis reflect the "Mediterraneity" of the reproductive strategy of this species with an adaptive response to altitudinal conditions. An early interruption of the spermatic activity, a short sexual rest and an early resumption of spermatogenic activity represent adaptations allowing compensating both the long hibernation period and the late emergence in spring (SAINTGirons \& DuguY, 1970). However, comparative studies between the different evolutionary lineages will be necessary to assess the geographical variations in their reproductive characteristics.

\section{Acknowledgement}

We are grateful to the anonymous reviewers for their comments on the earlier version of the manuscript. Also, we sincerely thank Mr Meribai Y. Director of the Djurdjura national park for permission. We are especially grateful to Moussa and Mohand for their unfailing support during our fieldwork. Animal handling followed humane treatment, and was in agreement with current laws of Algeria. We are also sincerely grateful to Dr. Merzouk Mamou for his help and to enable us to carry out the first steps of this work in Laboratory of analytical chemistry, Tizi Ouzou University.

\section{REFERENCES}

Abu-Zinadah, O.A. (2008). Variation in testicular histology of the spiny tailed lizard Uromastyx aegyptius microlepis during hibernation and active periods. Pakistan Journal of Biological Sciences 11: 1615-1619.

Al-Amri, I.S.; Mahmoud, I.Y.; Waring, C.P.; Alkindi, A.Y.; Khan, T. \& BAKheit, C. (2012). Seasonal changes in plasma steroid levels in relation to ovarian steroidogenic ultrastructural features and progesterone receptors in the house gecko, Hemidactylus flaviviridis, in Oman. General and Comparative Endocrinology 177: 46-54.

Al-Amri, I.S.; Mahmoud, I.Y.; Waring, C.P.; Alkindi, A.Y.; Khan, T.; Bakheit, C. \& Al -Mawali, K.M. (2013). The reproductive cycle of the male house gecko, Hemidactylus flaviviridis, in relation to plasma steroid concentrations, progesterone receptors, and steroidogenic ultrastructural features, in Oman. General and Comparative Endocrinology 187: 23-31. 
Aldridge, R.D. (1975). Environmental control of spermatogenesis in the rattle snake Crotalus viridis. Copeia 1975: 493496.

Amat, F.; Llorente, G.A. \& Carretero, M.A. (2000). Reproductive cycle of the sand lizard (Lacerta agilis) in its south western range. Amphibia-reptilia 21: 463-476.

Angelini, F.; Picariello, O. \& Botte, V. (1976). Influence of photoperiod and temperature on the testicular activity of the lizard, Lacerta s. sicula Raf. Bolletino di zoologia 43: 111123.

Angelini, F.; Brizzi, R. \& Barone, C. (1979). The annual spermatogenetic cycle of Podarcis sicula Campestre De Betta (Reptilia Lacertidae). Monitore Zoologico Italiano - Italian Journal of Zoology 13: 279-301.

Arnold, E.N.; Arribas, Ó. \& Carranza, S. (2007). Systematics of the Palaearctic and Oriental lizard tribe Lacertini (Squamata: Lacertidae: Lacertinae), with descriptions of eight new genera. Zootaxa 1430:1-86.

Arribas, O.J. \& Galán, P. (2005). Reproductive characteristics of the Pyrenean highmountain lizards: Iberolacerta aranica (Arribas, 1993), I. aurelioi (Arribas, 1994) and I. bonnali (LANTZ, 1927). Animal Biology 55: 163-190.

Braña, F.; Arrayago, M.J.; Bea, A. \& Barahona, A. (1990). Cicloreproductor y de cuerposgrasos en los machos de Lacerta monticola cantabrica. Comparación entre dos poblacionessituadas a diferente altitud. AmphibiaReptilia 11: 41-52.

Busack, S.D.; Lawson, R. \& Arjo, W.M. (2005). Mitochondrial DNA, allozymes, morphology and historical biogeography in the Podarcis vaucheri (Lacertidae) species complex. Amphibia-Reptilia 26: 239-256.

Carretero, M.A. (2006). Reproductive cycles in Mediterranean lacertids: plasticity and constraints, In C. Corti, P. Lo Cascio \& M. Biaggini (eds.) Mainland and Insular Lacertid Lizards: A Mediterranean Perspective. Fi- renze University Press, Firenze, Italy, pp. 33 -54 .

Carretero, M.A. \& Llorente, G.A. (1995). Reproduction of Acanthodactylus erythrurus in its Northern Boundary. Russian Journal of Herpetology 2: 10-17.

Carretero, M.A. \& LIorente, G.A. (1997). Reproduction of Psammodromus algirus in coastal sandy areas of NE Spain. AmphibiaReptilia 18: 369-382.

Carretero, M.A.; Perera, A.; Harris, D.J.; Batista, V. \& Pinho, C. (2006a). Spring diet and trophic partitioning in an alpine lizard community from Morocco. African Zoology 41: 113-122.

Carretero, M.A.; Ribeiro, R.; Barbosa, D.; SÁSousa, P. \& Harris, D.J. (2006b). Spermatogenesis in two Iberian Podarcis lizards: relationships with male traits. Animal Biology 56: 1-12.

Carretero, M. A.; Roca, V.; Larbes, S.; Ferrero, A. \& Jorge, F. (2011). Intestinal helminth parasites of wall lizards, Podarcis vaucheri complex (Sauria: Lacertidae) from Algeria. Journal of Herpetology 45: 385-388.

Castilla, A.M. \& Bauwens, D. (1990). Reproductive and fat body cycles of the Lizard, Lacerta lepida, in central Spain. Journal of Herpetology 24: 261-266.

Colli, G.R.; Mesquita, D.O.; Rodrigues, P.V.V. \& Kitayama, K. (2003). Ecology of the gecko Gymnodactylus geckoides amarali in a Neotropical Savanna. Journal of Herpetology 37: 694-706.

Damas-Moreira, I.; Harris, D. J.; Rosado, D.; Tavares, I.; Maia, J. P.; Salvi, D. \& Perera, A. (2014). Consequences of haemogregarine infection on the escape distance in the lacertid lizard, Podarcis vaucheri. Acta Herpetologica 9: 119-123.

Díaz, J.A.; Alonso-Gómez, A.L. \& Delgado, M.J. (1994). Seasonal variation of gonadal development, sexual steroids, and lipid reserves in a population of the lizard 
Psammodromus algirus. Journal of Herpetology 28: 199-205.

Domínguez, M.; Sanz, A.; Chávez, J. \& Almaguer, N. (2010). Cyclical reproduction in females of the Cuban lizard Anolis lucius (Polychrotidae). Herpetologica 66: 443 -450 .

Dunham, A.E. \& Miles, D.B. (1985). Patterns of covariation in life history traits of Squamate Reptiles: The effects of size and phylogeny reconsidered. The American Naturalist 126: 231-257.

Ferreira, A.; Silva, D.N.; Van Sluys, M. \& Dolder, H. (2009). Seasonal changes in testicular and epididymal histology of the tropical lizard, Tropidurus itambere (Rodrigues, 1987), during its reproductive cycle. Brazilian Journal of Biology 69: 429435.

Fiтch, W.M. (1970). Distinguishing homologous from analogous proteins. Systematic Biology 19: 99-113.

Flemming, A.F. (1993). The male reproductive cycle of the lizard Pseudocordylus m. melanotus (Sauria: Cordylidae). Journal of Herpetology 27: 473.

Galán, P. (1996). Reproductive and fat body cycles of the lacertid lizard Podarcis bocagei. Herpetological Journal 6: 20-25.

Galán, P. (1997). Reproductive ecology of the lacertid lizard Podarcis bocagei. Ecography 20: 197-209.

GoldberG, S.R. (2013). Reproduction in Bosk's Fringe-fingered Lizard, Acanthodactylus boskianus from Israel (Squamata: Lacertidae). Zoology in the Middle East 59: 16-19.

Gribbins, K. (2011). Reptilian spermatogenesis: A histological and ultrastructural perspective. Spermatogenesis 1: 250-269.

Hamdine, W.H.; Thévenot, M.; Sellami, M. \& De Smet, K. (1993). Régime alimentaire de la Genette (Genetta genetta Linné, 1758) dans le Parc national du Djurdjura, Algérie. Mammalia 57: 9-18.

Hammouche, S. \& Gernigon-Spychalowicz, T. (1996). La folliculogenèse chez le lézard
Uromastix acanthirunus (Sauria, Agamidae). Bulletin de la Société Herpétologique de France 78: 29-33.

Hammouche, S.; Gernigon-Spychalowicz, T. \& Exbrayat, J.M. (2007). Immunolocalization of estrogens and progesterone receptors within the ovary of the lizard Uromastyx acanthinura from vitellogenesis to rest season. Folia Histochemica et Cytobiologica 45: 23-22.

Hraoui-Bloquet, S. (1985). Le cycle sexuel des mâles chez Lacerta laevis (Reptilia, Lacertidae) dans les montagnes du Liban. Amphibia-Reptilia 6: 217-227.

Hraoui-Bloquet, S. \& Bloquet, G. (1988). Le cycle sexuel des mâles chez Lacerta laevis sur la côte du Liban et comparaison avec les lézards de montagne. Amphibia-Reptilia 9: 189-195.

Hraoui-Bloquet, S.; Sadek, R.; LahoudНокауем, M. \& Hakim-SAade, J. (2007). Cycle de reproduction chez les mâles d'Acanthodactylus schreiberi syriacus Böttger, 1879 (Reptilia, Lacertidae) du Liban. Bulletin de la Société Herpétologique de France 122: 5-18.

HuANG, W.-S. (2010). Ecology and reproductive characteristics of the skink Sphenomorphus incognitus on an East Asian Island, with comments on variations in clutch size with reproductive modes in Sphenomorphus. Zoological Studies 49: 779-788.

Ikeuchi, I. (2004). Male and female reproductive cycles of the Japanese Gecko, Gekko japonicus, in Kyoto, Japan. Journal of Herpetology 38: 269-274.

James, C. \& Shine, R. (1985). The seasonal timing of reproduction: A tropical-temperate comparison in Australian lizards. Oecologia 67: 464-474.

Jenssen, T.A. \& Nunez, S.C. (1994). Male and female reproductive cycles of the Jamaican lizard, Anolis opalinus. Copeia 1994: 767780 .

JöNsson, K.I. (1997). Capital and income breeding as alternative tactics of resource use in 
reproduction. Oikos 78: 57-66.

Kaliontzopoulou, A.; Pinho, C.; Harris, D.J. \& Carretero, M.A. (2011). When cryptic diversity blurs the picture: a cautionary tale from Iberian and North African Podarcis wall lizards. Biological Journal of the Linnean Society 103: 779-800.

Kaliontzopoulou, A.; Carretero, M.A. \& Llorente, G.A. (2012). Morphology of the Podarcis wall lizards (Squamata: Lacertidae) from the Iberian Peninsula and North Africa: patterns of variation in a putative cryptic species complex: Morphology of Iberian Podarcis. Zoological Journal of the Linnean Society 164: 173-193.

Larbes, S.; Carretero, M.A. \& Brito, J.C. (2007). Contribution à l'étude de la variabilité phénotypique du lézard des murailles Podarcis sp. dans deux régions d'Algérie du nord (Kabylie et Belezma), In T. Slimani (eds.) Abstract book First Mediterranean Herpetological Congress, Marrakech, Morocco, 16-20 April 2007, pp. 91.

Licht, P. (1971). Regulation of the annual testis cycle by photoperiod and temperature in the lizard Anolis carolinensis. Ecology 52: 240-252.

Licht, P. (1972). Environmental physiology of reptilian breeding cycles: Role of temperature. General and Comparative Endocrinology 3: 477-488.

Licht, P. (1973). Influence of temperature and photoperiod on the annual ovarian cycle in the lizard Anolis carolinensis. Copeia 1973: 465-472.

Licht, P.; Hoyer, H.E. \& van Oordt, P.G.W.J. (1969). Influence of photoperiod and temperature on testicular recrudescence and body growth in the lizards, Lacerta sicula and Lacerta muralis. Journal of Zoology 157: 469-501.

Lima, A.; Pinho, C.; Larbes, S.; Carretero, M.A.; Brito, J.C. \& Harris, D.J. (2009). Relationships of Podarcis wall lizards from Algeria based on mtDNA data. Am-
phibia-Reptilia 30: 483-492.

LofTs, B. (1978). Reptilian reproductive cycles and environmental regulators, In I. Assenmacher \& S.F. Donald (eds.) Environmental Endocrinology. Springer-Verlag Berlin Heidelberg, New York, USA, pp. 37-43.

Mamou, R.; Marniche, F.; Amroun, M. \& Herrel, A. (2016). Trophic ecology of two sympatric lizard species: the Algerian sand lizard and the wall lizard in Djurdjura, northern Algeria. Zoology and Ecology 26: 256-264.

Manríquez-Morán, N.L.; Cruz, M.V.-S. \& Méndez-de la Cruz, F.R. (2005). Reproductive biology of the parthenogenetic lizard, Aspidoscelis cozumela. Herpetologica 61: 435439.

Marion, K.R. (1982). Reproductive cues for gonadal development in temperate Reptiles: Temperature and photoperiod effects on the testicular cycle of the lizard Sceloporus undulatus. Herpetologica 38: 26-39.

Medina, M. \& Ibargüengoytía, N.R. (2010). How do viviparous and oviparous lizards reproduce in Patagonia? A comparative study of three species of Liolaemus. Journal of Arid Environments 74: 1024-1032.

Méndez-de la Cruz, F.R.; Cruz, M.V.-S.; LópezOrtíz, M.L. \& Hernández-Gallegos, O. (2013). Reproductive Cycle of a HighElevation, Oviparous Lizard (Sceloporus spinosus: Reptilia: Phrynosomatidae). The Southwestern Naturalist 58: 54-63.

Ochotorena, A.S.; Aranzábal, M.C.U. \& GuilLETTE, L.J. (2005). Seasonal gametogenic cycles in a Cuban tropical lizard, Anolis porcatus. Journal of Herpetology 39: 443-454.

Oliverio, M.; Bologna, M.A. \& Mariottini, P. (2000). Molecular biogeography of the Mediterranean lizards Podarcis WAgLer, 1830 and Teira Gray, 1838 (Reptilia, Lacertidae). Journal of Biogeography 27: 1403-1420.

Olsson, M. \& Shine, R. (1999). Plasticity in frequency of reproduction in an Alpine lizard, Niveoscincus microlepidotus. Copeia 1999: 794. 
Pianka, E.R. \& VitT, L.J. (2003). Lizards: Windows to the Evolution. University of California Press, USA.

Pinho, C.; Ferrand, N. \& Harris, D.J. (2006). Reexamination of the Iberian and North African Podarcis (Squamata: Lacertidae) phylogeny based on increased mitochondrial DNA sequencing. Molecular Phylogenetics and Evolution38: 266-273.

Pinho, C.; Harris, D.J. \& Ferrand, N. (2007). Comparing patterns of nuclear and mitochondrial divergence in a cryptic species complex: the case of Iberian and North African wall lizards (Podarcis, Lacertidae). Biological Journal of the Linnean Society 91: 121133.

Renoult, J.P.; Geniez, P.; Beddek, M. \& CroCHET, P.-A. (2010). An isolated population of Podarcis vaucheri (Sauria: Lacertidae) in southeastern Spain: genetic data suggest humanmediated range expansion. AmphibiaReptilia 31: 287-293.

Rizk, K. \& Nassar, F. (2015). Male reproduction cycle of Kulzer's rock lizard, Phoenicolacerta kulzeri (Müllen \& Wettstein, 1932), in Lebanon (Reptilia: Lacertidae). Zoology in the Middle East 61: 318-323.

Roig, J.M.; Carretero, M.A. \& Llorente, G.A. (2000). Reproductive cycle in a Pyrenean oviparous population of the common lizard (Zootoca vivipara). Netherlands Journal of Zoology 50: 15-27.

Saint-Girons, H. (1982). Reproductive cycles of male snakes and their relationships with climate and female reproductive cycle. Herpetologica 38: 5-16.

Saint-Girons, H. \& Duguy, R. (1970). Le cycle sexuel de Lacerta muralis en plaine et en montagn. Bulletin du Museum National d'Histoire Naturelle 42: 609-625.

Veríssimo, C. V. \& Carretero, M. A. (2009). Preferred temperatures of Podarcis vaucheri from Morocco: intraspecific variation and interspecific comparisons. AmphibiaReptilia 30: 17-23.

Villagrán-Santa Cruz, M.; HernándezGallegos, O. \& Méndez-de la Cruz, F.R. (2009). Reproductive cycle of the lizard Sceloporus mucronatus with comments on intraspecific geographic variation. Western North American Naturalist 69: 437-446.

Whittier, J.M. \& CRews, D. (1987). Seasonal reproduction: patterns and control, In D.O. Norris \& R.E. Jones (eds.) Hormones and Reproduction in Fishes, Amphibians, and Reptiles. Plenum Press, New York, USA, pp. 385409. 